\title{
A CASE STUDY OF ETHNO VILLAGE IN SLOVENIA AND BOSNIA AND HERZEGOVINA
}

\section{Andrej Raspor ${ }^{1}$, Petra Kleindienst ${ }^{1}$, Kildi Tjaša Peršič ${ }^{1}$, Zoran Mastilo², Draginja Borojevićc, Vesna Miletić ${ }^{2}$}

date of paper receipt:

18.09.2020.

Review Article date of sending to review:

21.09.2020.

doi: 10.2478/eoik-2020-0015 date of review receipt:

14.10.2020.

UDK 338.486.1.02(497.4)(497.6)

${ }^{1}$ School of Advanced Social Studies, Nova Gorica, Slovenia

${ }^{2}$ Oikos Institute-Research Center, Bijeljina, Bosnia and Herzegovina

\section{ABSTRACT}

Background: The world tourism industry is subject to big changes. A number of tourists traveling steadily grows, resulting in turnover and income. The destinations, that tourists are attracted, to are numerous, and there are also newcomers who arrive to a certain destination for the first time. Nowadays, even some very distant places are on the travellers' bucket lists. What is more, tourists are looking for authenticity, in terms of which the concept of ethno village proves to be such an example. Purpose: The purpose of this paper is to investigate how this kind of tourism is regulated in Slovenia and Bosnia and Herzegovina. The emphasis will be on the study of specific ethno villages.

Methods: Regarding the article, desk analysis will be done. The data were gathered from the world web, from the World Tourism Organisation's data and from the data gathered from Slovenian and Bosnian national statistical office as well. The Excel was used for the analyses. Two examples of an ethno village are also described.

Results: The ethno village as a part of rural tourism offers great opportunities for new work posts but capacities should be used to a greater extent and the problem of seasonality should also be overcome. All the key aims of rural development must be defined by the following strategy: the development of sustainable and efficient agricultural sector, the living standard of the population who lives from agriculture, creation of social and economic conditions in the rural regions; all of it within the National strategy of the rural development.

Conclusions: Tourism industry is being developing as a part of modern touristic migration. There are more and more visitors coming overseas or coming from more remote places. They stay for a short period of time and they have different expectations as before.

Keywords:

Slovenia, Bosnia and Herzegovina, cultural tourism, ethno village

JEL: L83 


\section{INTRODUCTION}

In the economic context of the 21st century, tourism is an essential activity in the structure of the economic mechanism and has an active role in the development and modernisation of the economy and society (Bunghez, 2016). It turns billions of dollars, and what is even more important, it is the generator of growth in different sectors of every national economy. In tourism the revenues per se are not high but tourism should be considered as a potential base for bigger GDP (Raspor, Stranjančević, Bulatović \& Lacmanović 2017).

Tourism can be divided into Business and Leisure (Hoang, n.d.), or into International and Domestic Tourism as well (Chand, n.d.). Further on, there is a difference between travel and tourism ('Difference Between Travel And Tourism, 2010). Tourism sector and tourism research community mainly focus on international inbound and outbound tourism; volumes and expenditures. However, international tourism is only one part of the whole picture. In some countries, domestic tourism represents a several times larger amount than international tourism (Raspor \& Mise-Srajlehner, 2017).

The future development of attractive destinations greatly depends on the safety of a certain destination. This is a beneficial starting point for Slovenia. However, an even greater challenge is the question how to use the trends for the sake of national benefit (Institute for Economics and Peace, 2016).

Economic valorisation of tourism is expressed through tourist spending. The scope and the structure of tourism consumption are the result of qualitative and quantitative composition of a tourism product at a destination and of any microeconomic tourism entity respectively (Lacmanović, 2006). Determining the scope, structure and effects of tourist spending at the level of international, national, regional or local economy represents a methodological problem due to the complexity of tourism as a socio-economic phenomenon (Antunac, 1985). In terms of economic activity, tourism is treated as an «invisible export» (Marković, 1972), due to the fact that the consumption of goods and services by foreign tourists really influences the export on the spot of a tourist destination (Raspor et al., 2017).

A new paradigm in the tourism industry changes the meaning of culture and its use in promoting several touristic products/services/experiences and destinations (Carvalho, Ferreira \& Figueira 2016). The importance of sustainability principles is being increasingly recognized in science and politics as the world is faced with several economic, environmental and social challenges (KorezVide, 2013). Cultural tourism is seen as a major growth market in Europe (Richards, 2002). Creative tourism is a form of cultural tourism (Ohridska-Olson \& Ivanov, 2010). The recognition of the economic potential of creativity and culture has set a culture-based creativity as a development tool and as a potential solution to the range of economic, social and environmental problems (i.e. new approaches to learning, new marketing approaches, developing social capital and community cohesion, environmental innovation etc.) (Korez-Vide 2013).

In line with the rise of experience economy and skilled consumption, the tourism, like other sectors, has undergone major transformations. Creative tourism could respond to the need of cultural tourism to reinvent itself as well as to the need of tourist destinations to do something different in a saturated market. It deeply involves tourists in the culturescape of a destination as they take part in different activities - such as crafts, arts, culinary and other creative activities. So far, only few studies explored the connections between sustainability and creative tourism development (KorezVide 2013). An intense relationship between tourism and creativity was studied by several authors throughout the last decade (Richards \& Wilson, 2007; Korez-Vide, 2013; Carvalho et al., 2016). However, it is not possible to find such studies in the territory of the countries, which were part of the former Yugoslavia. That is why we started with this research on Slovenia and on Bosnia and Herzegovina. In relation to that, we prepared a research question. The main goal of this article is to explore cultural and creative industries in the tourism sector of Slovenia and Bosnia and Herzegovina. Consequently, the findings would be a good starting point for further research. The scientific goal is to detect the needs in the field of cultural and creative industries. Theoretical 
purposes are a description of the current situation, an explanation of its effects and an assessment of the positive effects regarding the current way of warning about weaknesses.

In this survey, a number of research methods (general and specific) will be used. General scientific methods will be used regarding the content analysis (quantitative and qualitative), and the comparative method is used to determine the similarities and differences in terms of objectives, structure, impact and effects in both countries that are the subject of research. Specific scientific methods that will be used are analytical-synthetic method, statistical method and method of deduction and induction. In this study, depending on the needs assessment, the interview and questionnaire will be used.

The paper is organised into three parts and introduction. Part one deals with the literature review of tourism and cultural tourism. Part two presents the empirical data on ethno village. Part three discusses the main empirical findings in the context of literature; it offers some conclusions, explains the limitations of this paper and the direction of future research.

\section{LITERATURE REVIEW}

\subsection{DEFINITION OF ETHNO TOURISM AND CULTURAL TOURISM}

According to the definition of the World Tourism Organization, cultural tourism comprises the trips where the tourists aim to visit sites or events with cultural and historical value. This type of tourism offers the opportunity to potential visitors to enjoy past human accomplishments. One of the most important parts of cultural tourism is intangible cultural heritage, which is defined as practices, expressions, knowledge or skills that are recognized by particular communities as part of their cultural heritage (Goss, 2016).

Other features of cultural tourism are anthropological tourism, food and drink, historical tourism, arts-festival tourism, museums, heritage sites and ethno tourism that is also part of this introduction (Bolnick, 2003). This type of tourism also has a long history, which is expected to have a bright future as well. The World Tourism Organization also expects that cultural tourism will experience a $15 \%$ growth rate per year. What is important to mention is that this type of tourism mainly attracts high-spending visitors and does not cause damage to the environment or local culture (Richards, 2002). Cultural tourism also allows visitors to get immersed into the local culture such as traditional rituals or festivities. In doing so, both the locals and tourists can interact with each other. Cultural tourism includes monuments, architectural complexes or symbols and also religious, educational or informative events. Such events provide knowledge to tourists about specific destinations and also help to improve the local economic growth (Aiello, 2014). The other conceptual definition describes cultural tourism as the movements of people away from their place of residence and towards cultural attractions. Those people are headed there to gather new information and experiences that will satisfy their cultural needs (Richards, 2003).

Regarding the types of cultural tourists, there are two main categories; the one is called a general cultural tourist, whose hobby is visiting different geographical places. Throughout the time and with the increase of their cultural knowledge of different places, they might become so-called specialized cultural tourists, i.e. who focus more on one or on a small number of places or entities. They visit a particular place repeatedly in order to obtain a deeper understanding of a place. There are also other types of cultural tourists such as serendipitous, incidental, casual, purposeful or sightseeing cultural tourists: they differ according to their personal interests. For example, in the case of a purposeful cultural tourist, his or her primary reason to visit a certain destination is cultural tourism but also his or her deep cultural experience (Mousavi, Doratli, Mousavi, \& Moradiahari, 2016).

Because of the importance that European Union gives to the culture and tourism but also owing to the importance that the Europe has on the global scale as touristic destination, we can see many 
initiatives that are trying to promote cultural tourism on the EU level. There are many projects funded or supported by European Union such as the European cultural routes; i.e. transnational routes on which the tourists can learn how Europeans have lived since ancient times. These routes have proved itself as a great booster for the local economies and societies. The European Commission regularly publishes calls for proposals in order to support creation of new either physical or virtual cultural routes (European Commission, 2018).

Another important initiative that was established in 1985 and has been active for more than thirty years, is called European Capitals of Culture. It is considered to be one of the most successful programmes founded by EU. Its main aim is to promote cultural diversity in Europe but also to improve and develop the cities and regions that participate in the programme. Therefore, it also contributes to the promotion of cultural tourism ('European Capitals of Culture - Regional Development and Culture', 2019).

\subsection{ETHNO TOURISM}

The rural tourism development process involves many social actors who continually reshape and transform plans and policy through interaction and negotiation. Local people are not passive recipients of the consequences of rural tourism development policy. On the contrary, they are capable of making the most out of a given situation (i.e. initiating a developmental project through the bottom-up approach) (Verbole, n.d.).

In the case of ethno tourism we talk about the type of tourism in which tourists are seeking authenticity in their trips. They explore indigenous populations, their culture and also their traditions. This type of tourism is giving the opportunity to the tourists to understand the lifestyle of local people (Jaunter, 2018).

This also includes a direct contact between tourists and indigenous people. Tourists can visit the houses, enjoy typical local food and even observe their cultural practices such as rituals, festivals or dances. Such concept of ethno tourism also brings some disadvantages such as tourists bringing various diseases to the local population and, to some extent, polluting the environment where indigenous people live (Burns \& Novelli, 2008).

There are some core aspects of ethno tourism; the majority of the aspects of the industry are controlled by tour operators and the consumers are mainly targeted through different channels such as international travel agents and travel shows or through internet offers. It is also important to mention that ethno tourism is predicted to increase due to its high popularity. Another great advantage of ethno tourism is that it creates and generates revenues very rapidly. Moreover, there are additional advantages such us low cost of job creation and the boost for the local economy through sales of local products or services (Bolnick, 2003; Bolnick 2003: 8-9).

However, if ethno tourism is not managed responsibly, it can have bad influence on indigenous people. What is more, tourism companies are trivialising and stereotyping cultures and their traditions in order to provide greater experience to a tourist, at his or her request. On many occasions the homes of the indigenous people and communities were turned into tourist attractions. Another problem can occur when tourist companies are using cultural heritage in order to make profit an at the same time declining a compensation to the owners of that particular cultural heritage. Very often local people do not have a choice because they would lose (often) the only source of the boost for their economy (Heurtier, 2017).

In the world, the current trend of tourism development is rural tourism, partially because during bathing seasons narrow sea shores become overcrowded by the tourists and the number of tourists is increasing in the world (Medojevic, Milosavljevic, \& Punisic, 2011). 
Despite that, one great advantage of ethno tourism is that it offers protection to the cultures that are being undermined by dominant world cultures in the context of globalization, if conducted responsible. And that is the demand of tourists from dominant cultures for preservation of the indigenous cultures through tourism (Bolnick, 2003).

There are some requirements identified by indigenous organizations that are supposed to help the governments sustain indigenous communities and minimize the impact of tourism on them. Those requirements are: (1) recognition of sovereignty for indigenous people and their land. (2) The second requirement is that tourism should operate within the framework from which indigenous people can gain full benefits. (3) The third requirement is all about comprehensive planning where tourism is built under the management of indigenous people. (4) In terms of the fourth requirement, indigenous people should also be in charge of the evaluation and monitoring of environmental and cultural impacts of ethnic tourism. (5) The fifth requirement states that the use of natural, biological or genetic resources from territories of indigenous people should be subject to the agreement signed by indigenous people as a sign of consent. (6) The sixth requirement says that government should support and help indigenous people or groups with planning, information exchange and capacity building. (7) The seventh and the last requirement states that the government of a particular country should foster the construction of the indigenous people's capacity to take up the decision making role regarding cultural knowledge and practices (Verner, 2009).

In the 70's the tourists ate dinner at a hotel. In the 80's they started discovering local restaurants. In 00 's they ventured into the homes of locals and now in 10's the tourists want to go with their local host to the market to buy the ingredients to make dinner together. What will the future bring? Perhaps tourists will want to raise the vegetables and the animals themselves to sell them on the market ... (Steinberg, 2015).

There is high probability of a future steady growth in ethno tourism due to various factors such as a higher number of participating countries, higher atractivity for tourists or changes of interests among urban population and youth whose income is exponentially increasing as they are becoming economically active in their countries. The attractivity of ethno tourism is also increased and fostered by governments, media or private sectors by introducing new touristic schemes (Karantzavelou, 2017).

Rural tourism development in the function of village revitalization enables rural population to gain certain benefits at the micro-economic level such as follows (Medojevic et al., 2011):

- Starting economic activities in a certain region

- Additional financing of rural households

- Creation of personal and cultural exchanges among the population

- Motivating population for the aim of shared activities and projects

- Boosting the enthusiasm of people for taking part in beneficial activities that concern all.

\section{METHOD}

In this survey, a number of combined techniques and a specific research methodology will be used to prove the facts and to draw conclusions. The research based on an exploratory, descriptive and causal approach will be complemented by basic scientific research methods: deduction / induction, methods of analysis and synthesis, and descriptive, historical and comparative methods. A number of quality literature sources was the basis for the theoretical reference to the concept of ethno tourism.

In the research quantitative methods are of particular importance since the use of statistically mathematical methods allows for the qualitative interpretation of empirical facts and the findings 
of conclusions. Tabular graphical representations will provide a more objective insight into the state of ethno and rural tourism and a clearer presentation of Slovenia and BiH's position in the tourism market.

In order to make the work of greater practical importance, two ethno villages were presented, one in Slovenia and the other in Bosnia and Herzegovina, which were investigated by comparative analysis.

The methods of analysis and synthesis adequately systematize the basic determinants of tourism development in the period 2010-2018, which gives insight into the trend of tourism development for both countries.

As a result of the limited volume of the present study, the research was reduced to a presentation of the real situation of ethno tourism in both countries, from which the conclusions about possible corrective actions can be drawn; the measures that can involve all interest groups in the field of tourism and related activities. The paper provides a fundamental basis for further scientific research.

\section{RESULTS}

\subsection{SLOVENIA}

Some rural areas of Slovenia, such as Gorenjska (Upper Carniola) and the Upper Savinja Valley, have a long tradition of rural tourism, or more specifically, agritourism, going back to the nineteenth century, and which was well established by the 1930s. After the Second World War tourism in rural areas stagnated as efforts were redirected to the development of tourist resorts in coastal and mountainous areas (Verbole, n.d.). A real boom in agritourism occurred in the late 1970s, fuelled in part by the government's growing concern to secure additional income for mountain farmers related to the small size of the farms, limited production conditions and continuing depopulation trends - and helped along by the public agricultural advisory service, which trained special advisors for supplementary activities and work for farm families (Verbole, 1995).

\subsubsection{STATISTICAL DATA OF SLOVENIAN TOURISM}

In the years 2008-2018 we can see the growth of tourist arrivals (Table 1: Statistical data of Slovenian tourism). In 2018 Slovenia recorded over 15,694,705 tourist overnight stays ('Accommodation establishments capacity, tourist arrivals and overnight stays in tourist accommodation establishments, Slovenia, annually', 2019). While the economic importance of tourism to Slovenia is a central characteristic, there are differences in its profile regarding different types of tourism, including the distinctions at regional level. Each type of tourism and each specific region are oriented towards different types of tourists. Daytrip visitors are more often in museums and in the city centres. There are currently 850 tourist farms in Slovenia ('Podeželje', 2019). 
Table 1. Statistical data of Slovenian tourism

\begin{tabular}{|c|c|c|c|c|c|c|}
\hline & & $\begin{array}{l}\text { Bed places - } \\
\text { TOTAL }\end{array}$ & $\begin{array}{c}\text { Tourist arrivals } \\
\text { - TOTAL }\end{array}$ & $\begin{array}{c}\text { Tourist arrivals } \\
\text { - foreign }\end{array}$ & $\begin{array}{c}\text { Overnight } \\
\text { stays - TOTAL }\end{array}$ & $\begin{array}{c}\text { Overnight } \\
\text { stays - foreign }\end{array}$ \\
\hline \multirow{4}{*}{2010} & 0 Tourist accommodation establishments - TOTAL & 153.909 & 3.299 .537 & 2.048 .981 & 9.883 .920 & 5.531 .218 \\
\hline & $\begin{array}{l}1 \text { Hotels and similar accommodation } \\
\text { establishments }\end{array}$ & 54.351 & 2.148 .268 & 1.497 .862 & 6.159 .794 & 3.926 .782 \\
\hline & 2 Camping sites & 26.736 & 380.172 & 219.327 & 1.249 .806 & 656.814 \\
\hline & 3 Other accommodation establishments & 72.823 & 771.097 & 331.792 & 2.474 .320 & 947.622 \\
\hline \multirow{4}{*}{2011} & 0 Tourist accommodation establishments - TOTAL & 152.737 & 3.535 .794 & 2.236 .157 & 10.413.012 & 6.049 .665 \\
\hline & $\begin{array}{l}1 \text { Hotels and similar accommodation } \\
\text { establishments }\end{array}$ & 55.427 & 2.290 .821 & 1.608 .133 & 6.509 .232 & 4.231 .080 \\
\hline & 2 Camping sites & 29.802 & 424.323 & 254.784 & 1.366 .968 & 755.164 \\
\hline & 3 Other accommodation establishments & 67.508 & 820.650 & 373.240 & 2.536 .812 & 1.063 .421 \\
\hline \multirow{4}{*}{2012} & 0 Tourist accommodation establishments - TOTAL & 155.022 & 3.635 .688 & 2.376 .651 & 10.604 .352 & 6.441 .086 \\
\hline & $\begin{array}{l}1 \text { Hotels and similar accommodation } \\
\text { establishments }\end{array}$ & 55.466 & 2.330 .971 & 1.679 .477 & 6.526 .045 & 4.386 .816 \\
\hline & 2 Camping sites & 29.319 & 427.758 & 261.341 & 1.395 .519 & 797.355 \\
\hline & 3 Other accommodation establishments & 70.237 & 876.959 & 435.834 & 2.682 .789 & 1.256 .914 \\
\hline \multirow{4}{*}{2013} & 0 Tourist accommodation establishments - TOTAL & 157.399 & 3.746 .106 & 2.501 .682 & 10.708 .408 & 6.671 .802 \\
\hline & $\begin{array}{l}1 \text { Hotels and similar accommodation } \\
\text { establishments }\end{array}$ & 55.863 & 2.370 .659 & 1.732 .861 & 6.516 .517 & 4.453 .860 \\
\hline & 2 Camping sites & 28.948 & 432.474 & 267.328 & 1.398 .087 & 827.748 \\
\hline & 3 Other accommodation establishments & 72.588 & 942.973 & 501.493 & 2.793 .804 & 1.390 .193 \\
\hline \multirow{4}{*}{2014} & 0 Tourist accommodation establishments - TOTAL & 158.087 & 3.901 .563 & 2.675 .071 & 10.738 .766 & 6.833 .040 \\
\hline & $\begin{array}{l}1 \text { Hotels and similar accommodation } \\
\text { establishments }\end{array}$ & 55.714 & 2.509 .949 & 1.859 .668 & 6.577 .092 & 4.544.209 \\
\hline & 2 Camping sites & 29.004 & 403.874 & 259.565 & 1.308 .068 & 792.412 \\
\hline & 3 Other accommodation establishments & 73.368 & 987.740 & 555.838 & 2.853 .607 & 1.496 .419 \\
\hline \multirow{4}{*}{2015} & 0 Tourist accommodation establishments - TOTAL & 165.641 & 4.373 .878 & 3.022 .018 & 11.653 .764 & 7.481 .657 \\
\hline & $\begin{array}{l}1 \text { Hotels and similar accommodation } \\
\text { establishments }\end{array}$ & 56.239 & 2.733 .166 & 2.037 .474 & 6.938 .840 & 4.809 .775 \\
\hline & 2 Camping sites & 31.743 & 459.243 & 291.718 & 1.452 .748 & 871.158 \\
\hline & 3 Other accommodation establishments & 77.659 & 1.181 .469 & 692.827 & 3.262 .175 & 1.800 .724 \\
\hline \multirow{4}{*}{2016} & 0 Tourist accommodation establishments - TOTAL & 170.096 & 4.834 .071 & 3.396 .873 & 12.647 .876 & 8.339 .978 \\
\hline & $\begin{array}{l}1 \text { Hotels and similar accommodation } \\
\text { establishments }\end{array}$ & 57.337 & 2.980 .525 & 2.253 .340 & 7.484 .815 & 5.291 .965 \\
\hline & 2 Camping sites & 32.616 & 497.375 & 316.496 & 1.510 .973 & 930.474 \\
\hline & 3 Other accommodation establishments & 80.143 & 1.356 .171 & 827.037 & 3.652 .088 & 2.117 .539 \\
\hline \multirow{4}{*}{2017} & 0 Tourist accommodation establishments - TOTAL & 174.926 & 5.503 .284 & 3.990 .682 & 14.208 .545 & 9.685 .329 \\
\hline & $\begin{array}{l}1 \text { Hotels and similar accommodation } \\
\text { establishments }\end{array}$ & 59.268 & 3.315.531 & 2.536 .946 & 8.134 .661 & 5.826 .129 \\
\hline & 2 Camping sites & 31.377 & 601.912 & 420.995 & 1.830 .805 & 1.233 .441 \\
\hline & 3 Other accommodation establishments & 84.281 & 1.585 .841 & 1.032 .740 & 4.243.079 & 2.625 .759 \\
\hline \multirow{4}{*}{2018} & 0 Tourist accommodation establishments - TOTAL & 192.136 & 5.933 .266 & 4.425 .139 & 15.694 .705 & 11.176 .010 \\
\hline & $\begin{array}{l}1 \text { Hotels and similar accommodation } \\
\text { establishments }\end{array}$ & 60.438 & 3.366 .707 & 2.619 .314 & 8.342 .743 & 6.149 .890 \\
\hline & 2 Camping sites & 36.373 & 648.149 & 471.637 & 1.934 .060 & 1.349 .575 \\
\hline & 3 Other accommodation establishments & 95.325 & 1.918 .411 & 1.334.187 & 5.417 .902 & 3.676 .544 \\
\hline
\end{tabular}

\subsubsection{GREEN TOURISM IN SLOVENIA}

The Slovenian Tourist Board ('Green Tourism - Slovenia - Official Travel Guide', 2017) is committed to make green and sustainable the watchwords that permeate its every activity. The main strategic objectives of green tourism include the active focus of tourism on the green economy, providing information and encouragement for the tourism industry to develop green business models, encouragement for destinations to set up sustainable development models and raising the awareness of a tourist. In relation to all that, the Green Scheme of Slovenian Tourism Slovenia Green was developed. This can be seen as a good platform for the development of health tourism, which will possibly be a big booster for the whole country because it enables the whole range of service providers, that till now had not identify themselves with the tourism industry to enter into it. New possibilities for growth are here but for sure it will not grow without cooperation and support.

The Slovenian Outdoor product is among the most competitive products in Europe, and it is based on natural elements, high-quality infrastructure, sustainable business practices, and the responsible use of natural and cultural features. The product is successfully integrated with other products (Health 
and Wellness, Holidays in the Mountains, Touring, Gastronomy), so it has obtained a significant critical mass, which has enabled investments into innovations, development, renovations, and the construction of new offerings. The product is an important catalyst for agricultural production, high-quality authentic cuisine, authentic accommodation offers, and numerous experiences in contact with nature, culture, and people.

\subsubsection{CASE STUDY OF THE “VELIKA PLANINA” ETHNO VILLAGE TOURISM OFFER}

The Slovenia Eco Resort is the unique and original concept of an ethnic village where the tourists or locals can experience a new type of adventurous tourism with many different activities. It was established by Matjaž Zorman in 2015 (Kos, 2018). It is located in central Slovenia in the valley of Velika Planina, just at the foothills of the Kamnik-Savinja Alps, 20 minutes northeast from the Ljubljana Jože Pučnik Airport (also known by its previous name Brnik Airport), which is the main airport in Slovenia ('Experience the fairytale of Velika Planina in a valley', 2019).

The tourists can be accommodated into 17 wooden cottages or glamping huts where they have all the necessary space for their comfort such as bedroom, living room, kitchen, bathroom, and terrace. All types of accommodations are equipped with electricity, Wi-Fi and heating system. While enjoying the stay tourists can experience local food, if they order homemade food from the local area ('Experience the fairytale of Velika Planina in a valley', 2019).

The Eco Resort offers to the tourists who prefer tranquillity, private finish sauna and also massages to renew the body. For the tourists that prefer a more active way of spending time during their holidays, the Eco Resort offers cycling or hiking trips with the guide that will show you the surroundings of the area. During the wintertime, tourists can go skiing to the nearby Velika Planina resort. The mentioned resort even offers wedding services to the people that are planning to get married ('Experience the fairytale of Velika Planina in a valley', 2019).

Moreover, the Eco Resort offers tourist packages tailored to many different occasions. Among those packages, we can find "Paradise for families in the embrace of the future" with which a tourist has an opportunity to taste fine local wine or "Family holidays in nature". The Eco Resort also offers the opportunity to organize team-building events which might be interesting for companies from close countries such as Croatia, Austria or Hungary. The regular price for the cottage ranges between EUR 130 and 195 per night and depends on the period of the year. In the case of the hut, this price is from EUR 65 to 80 ('Experience the fairytale of Velika Planina in a valley', 2019).

The Slovenia Eco resort also offers a job to all the adventure seekers that might be interested in working. Among the duties that will have to be fulfilled, are taking care of animals, of the garden and of the wellness with a natural swimming pool and guiding activities and workshops for children ('Experience the fairytale of Velika Planina in a valley', 2019).

There are plenty of benefits that a potential worker will be able to enjoy, such as local, fresh and healthy food, free wellness facilities, job and anti-stress program and, what is more, the natural and fresh environment in the mountains. This can be a great opportunity to run away from the daily life in the city or the opportunity to experience something new ('Experience the fairytale of Velika Planina in a valley', 2019).

The Eco Resort offers two concepts in terms of Slovenia: the first is cultural tourism and the second is the concept of ethno or ethnic village. In the next few paragraphs both terms will be presented. Firstly, let's define what does cultural tourism mean. 


\subsection{BOSNIA AND HERCEGOVINA}

\subsubsection{STATISTICAL DATA OF BOSNIA AND HERZEGOVINA TOURISM}

Tourism in Bosnia has been experiencing a real expansion in the last years. If we take a look at the table below, the number of tourists has steadily increased, except for the period 2014-2015, when tourist visits stagnated in Bosnia and Herzegovina (Table 2: Statistical data of Bosnia and Herzegovina tourism). Since 2013 the classification of accommodations was revised so that camps and resorts are a separate category and hotels and motels form the same category, which was not the case until then. The number of nights spent in camps has increased dramatically since 2016.

Table 2. Statistical data of Bosnia and Herzegovina tourism

\begin{tabular}{|c|c|c|c|c|c|}
\hline & & $\begin{array}{c}\text { Tourist arrivals - } \\
\text { TOTAL }\end{array}$ & $\begin{array}{c}\text { Tourist arrivals - } \\
\text { foreign }\end{array}$ & $\begin{array}{c}\text { Overnight stays } \\
\text { - TOTAL }\end{array}$ & $\begin{array}{c}\text { Overnight } \\
\text { stays - foreign }\end{array}$ \\
\hline \multirow{6}{*}{2010} & 0 Tourist accommodation establishments - TOTAL & 610.817 & 321.511 & 1.416 .691 & 772.754 \\
\hline & 1 Hotels & 499.695 & 279.148 & 1.103 .637 & 673.285 \\
\hline & 2 Motels & 54.795 & 22.012 & 96.413 & 41.316 \\
\hline & 3 Boarding houses and hostels & 30.921 & 9.465 & 50.627 & 28.501 \\
\hline & 4 Private room & 4.871 & 2.117 & 5.348 & 2.737 \\
\hline & 5 Apartments and other & 20.527 & 8.769 & 160.666 & 26.915 \\
\hline \multirow{6}{*}{2011} & 0 Tourist accommodation establishments - TOTAL & 686.148 & 391.945 & 1.504 .205 & 836.005 \\
\hline & 1 Hotels & 559.397 & 352.926 & 1.167 .735 & 741.556 \\
\hline & 2 Motels & 58.734 & 18.127 & 94.535 & 36.742 \\
\hline & 3 Boarding houses and hostels & 24.291 & 9.286 & 53.397 & 28.542 \\
\hline & 4 Private room & 3.776 & 883 & 5.296 & 1.866 \\
\hline & 5 Apartments and other & 40.050 & 10.723 & 183.242 & 27.292 \\
\hline \multirow{6}{*}{2012} & 0 Tourist accommodation establishments - TOTAL & 747.827 & 438.585 & 1.645 .521 & 931.081 \\
\hline & 1 Hotels & 610.115 & 390.355 & 1.282 .622 & 825.967 \\
\hline & 2 Motels & 59.495 & 20.243 & 100.150 & 39.323 \\
\hline & 3 Boarding houses and hostels & 22.410 & 7.616 & 41.644 & 19.074 \\
\hline & 4 Private room & 5.061 & 1.588 & 7.527 & 3.281 \\
\hline & 5 Apartments and other & 50.746 & 18.783 & 213.578 & 43.436 \\
\hline \multirow{5}{*}{2013} & 0 Tourist accommodation establishments - TOTAL & 844.189 & 528.579 & 1.822 .927 & 1.108 .905 \\
\hline & 1 Hotels and similar accommodations & 806.112 & 509.076 & 1.677 .616 & 1.063 .355 \\
\hline & 2 Holiday and other short stay accommodations & 15.702 & 8.518 & 33.517 & 22.278 \\
\hline & 3 Camps & 10.012 & 8.532 & 15.621 & 13.846 \\
\hline & 4 Other accommodations & 12.363 & 2.453 & 96.173 & 9.426 \\
\hline \multirow{5}{*}{2014} & 0 Tourist accommodation establishments - TOTAL & 75.878 & 38.949 & 157.283 & 88.192 \\
\hline & 1 Hotels and similar accommodations & 72.907 & 37.912 & 147.973 & 85.231 \\
\hline & 2 Holiday and other short stay accommodations & 1.867 & 810 & 4.033 & 2.289 \\
\hline & 3 Camps & 37 & 19 & 51 & 33 \\
\hline & 4 Other accommodations & 1.067 & 208 & 5.226 & 639 \\
\hline \multirow{5}{*}{2015} & 0 Tourist accommodation establishments - TOTAL & 95.026 & $51 . .024$ & 209.482 & 120.728 \\
\hline & 1 Hotels and similar accommodations & 90.684 & 48.885 & 200.200 & 115.570 \\
\hline & 2 Holiday and other short stay accommodations & 3.156 & 1.784 & 6.677 & 4.230 \\
\hline & 3 Camps & 34 & 13 & 34 & 13 \\
\hline & 4 Other accommodations & 1.152 & 342 & 2.571 & 915 \\
\hline \multirow{5}{*}{2016} & 0 Tourist accommodation establishments - TOTAL & 1.150 .039 & 778.128 & 2.383 .056 & 1.647 .275 \\
\hline & 1 Hotels and similar accommodations & 1.076 .866 & 730.622 & 2.199 .242 & 1.535 .628 \\
\hline & 2 Holiday and other short stay accommodations & 40.480 & 26.610 & 85.666 & 62.192 \\
\hline & 3 Camps & 12.090 & 10.095 & 21.308 & 19.033 \\
\hline & 4 Other accommodations & 20.603 & 10.801 & 76.840 & 30.422 \\
\hline \multirow{5}{*}{2017} & 0 Tourist accommodation establishments - TOTAL & 1.307 .319 & 923.050 & 2.383 .056 & 1.647 .275 \\
\hline & 1 Hotels and similar accommodations & 1.226 .719 & 870.061 & 2.199 .242 & 1.535 .628 \\
\hline & 2 Holiday and other short stay accommodations & 46.533 & 31.916 & 85.666 & 62.192 \\
\hline & 3 Camps & 12.656 & 11.601 & 21.308 & 19.033 \\
\hline & 4 Other accommodations & 21.411 & 9.472 & 76.840 & 30.422 \\
\hline \multirow{5}{*}{2018} & 0 Tourist accommodation establishments - TOTAL & 1.292 .636 & 951.122 & 2.702 .502 & 1.955 .581 \\
\hline & 1 Hotels and similar accommodations & 1.205 .859 & 896.377 & 2.461 .429 & 1.827 .026 \\
\hline & 2 Holiday and other short stay accommodations & 50.903 & 35.674 & 111.874 & 84.198 \\
\hline & 3 Camps & 14.228 & 12.590 & 24.186 & 22.047 \\
\hline & 4 Other accommodations & 21.646 & 6.481 & 105.013 & 22.310 \\
\hline
\end{tabular}

Source: ('Agencija za statistiku BiH', 2020) 


\subsubsection{RURAL TOURISM IN BOSNIA AND HERZEGOVINA}

Fortunately, there are many initiatives that deal with the development of rural tourism in Bosnia and Herzegovina, which are mostly sponsored by international non-governmental organizations. Their results are reflected in the fact that thanks to the small donations received, they are able to explore the possibilities and plan the development of new destinations, provide assistance to farmers by introducing them to the tourism aspect of their home or organizing different study trips. The total contribution of tourism to our country's GDP is only 7 percent but the authorities, with their activities of strengthening tourist activities and attracting foreign tourists, show a desire to increase the number. The data regarding the number of tourists who visited Bosnia and Herzegovina in the first four months of 2019 are not yet known but tourist experts assume that the growth trend will continue to be seen. In the city of Bijeljina, there was an increase in arrivals and overnight stays of $5.1 \%$ in 2018, as opposed to 2017. According to the official data of the tourist organization of Bijeljina, 30,000 tourists had 57,000 overnight stays in 2017. Bijeljina is planning to increase the number of foreign tourists by $19 \%$ in comparison to the last year. According to the analysis of the tourist organization, a limiting factor for the development of tourism in Semberija is a small number of accommodation capacities with 830 beds, although in the «Stanišići» ethno village there are two five-star hotels out of five such hotels in the Republic of Srpska. Regarding market surveillance, it was reinforced through tax inspection and the suppression of grey economy. Besides, the number of rented apartments per day went up. Consequently, all together resulted in a significant increase in the records of tourists and realized overnight stays. In the structure of foreign tourists who visited Bijeljina in 2017, 45\% are guests from Serbia, as well as from Slovenia, Croatia, Germany and Switzerland. Of the total percentage, $70 \%$ are foreign guests who reside in the ethno village upon their arrival in Bijeljina.

The «Stanišići» ethno village brings a whole new experience to its visitors who want to go on a guided tour of the complex of this tourist gem. From now on, the tourists will be able - with the help of audio-guides with the headphones - to listen to an interesting and authentic story about each of the facilities. The idea of that new touristic offer is based on the reputation of the famous "Alcatraz prison» on the island of the same name near San Francisco.

The «tour» through the ethno village lasts about 32 minutes and at the visitor's request it can be interrupted at any time, so that he or she can take photos and continue on, so the tour can take more time. One similar ethno village that is the closest to this area, is situated only in Vienna in Austria. Each year the Stanišići ethno village hosts a forum of managers; the themes are education and development of individuals who represent the most important human capital. Such forum is very important because it's the place where tourism and economy come together, whereas the participants have a chance to develop nice and useful acquaintances, and they can also get an inspiration for their own further progress and improvements.

Alterural, an association for the promotion and professionalization of rural tourism in Bosnia and Herzegovina, made an important contribution to the concept of ethno village. The goal is to present pristine nature that has enormous potential and wealth, in the form of products and services that can be fully extended to the tourist season in all four seasons.

\subsubsection{CASE STUDY OF THE «STANIŠIĆI» ETHNO VILLAGE TOURIST OFFER}

In 2003 an idyllic mountain village was created in the plain near Bijeljina. The idea was conceived and realized by Boris Stanišić, who had been collecting ideas for Central Bosnia. The village is devoted to the culture and the spirit of the old times and adapted to the needs of the 21st century ('Etno selo - official', 2019).

In 2003 the tavern in «Stanišići» opened what turned out to be a success, proven also by the visitors' good attendance. The first guests were the locals. Gradually and thanks to start-up capital, they started with attracting tourists from other parts of the country and foreigners as well. This ethno 
complex is located at the end of Bijeljina, on Pavlovica road, near the border with Serbia. Today the "Stanišići» ethno village looks like a modern fairy tale that deserves to be among the first destinations that you must visit upon your arrival in the Republic of Srpska. During the visit to the ethno village, you can visit the museum, the watermill (which still mills flour for the needs of the restaurant and the kitchen), the Podlugovi train station and the preserved identical mountain houses (among which are the «House of grandpa Božo» and "Rosulje House») and you can also enjoy religious tourism. The Church of «St. Nicholas» is the most visited part of the ethno village. In the church there is a weekly mass, and it is also the place where many young couples make a vow of everlasting love and some of them later even baptize their own children. Already halfway through the sightseeing of this complex, you can find rest in the many restaurants that this place offers. The «Konoba Stanišići» restaurant has 200 seats in first dining area, 65 seats in the second, and also 100 seats on its terraces. The tavern is located on the very shore of the lake and is fully dressed in ethno style. It offers a wonderful view on the museum of «Stanišići» ethno village. The «E $\lambda \lambda \dot{\alpha} \varsigma$ » (i.e. «Greek») building was built in a stone-wood combination and it was integrated into the «Pirg» hotel. In addition to gastronomic delights, you can also celebrate children's birthdays with karaoke; for children up to 12 years. The «Vasojević» pub is an ethno café with a good homemade brandy, and it provides special pleasure in the winter days. The «Stanišići» ethno village has two hotels: «Pirg» and «Ras». The»Pirg» hotel has 5 stars and is the right place to relax your soul and body. To make the atmosphere complete, there are massage centres, fitness, swimming pool, jacuzzi, cocktail lounge, balcony and TV. Even if your visit is business-related, quality holiday is still a guarantee for you.

The «Ras» hotel is also a 5-star hotel. It provides the same but maybe better conditions than "Pirg". It has the capacity to accommodate 160 guests in the rooms that can be single, double and rooms with extra bed. The «Ras» hotel is specific because the complex includes three festive shops - «St. Petersburg», «Moscow» and "Volga» - with which it is connected by the elevator and the staircase. All festive halls - depending on the opportunity - can range from 100 to 1,500 guests. Also, their appearance can be adapted to the type of a certain event: from the congress to the conference ('Bijeljina online', 2018). In addition to ethno museums, restaurants, hotels, mountain lodges, festive halls, stadiums and sports fields, within the tourist complex «Stanišići» ethno village, there is a newly built and modern «LEONIDA» Wellness \& SPA centre that lies on the area of 2,500 $\mathrm{m}^{2}$ ('Trip.com', 2019).

The centre was designed according to the existing architectural solutions in the «Stanišići» ethno village and is adapted to the ambience of the village, and maintains a warm connection with the «RAS» hotel. The «LEONIDA» Wellness \& SPA Centre has an indoor swimming pool, sauna centre, massage and hydro massage bathtubs, steam baths, beauty salons and a modern fitness centre, which is needed for the best rest and relaxation of visitors and guests in the «Stanišići» ethno village. However, everything was not always in a perfect state. In 2014 the entire complex was hit by the floods that lasted for 21 days.

Preserving the tradition and customs of certain areas of Bosnia and Herzegovina is becoming important for an increasing number of local residents from different profiles. By their example, many enthusiasts contribute to preserving their traditions and customs and protecting the environment. In the rural areas of Bosnia and Herzegovina the number of new and interesting places is growing every day. These can be new slopes on the mountains, plains or valleys where one can experience a traditional way of life and natural beauty that has immeasurable value. In these areas people, who try to preserve the traditions and nature, will welcome you with open arms. Although not sufficiently fast and in not the most effective way, rural tourism in Bosnia and Herzegovina is still recognized as one of the branches of tourism, which is continuing to grow due to individuals, local communities and not least because of the Federation of Bosnia and Herzegovina and Republic of Srpska. Rural tourism, especially in relation to the accommodations in rural areas, has great potential for tourism development in general. However, we can say that rural tourism in Bosnia and Herzegovina is still in its infancy. ('Etno selo - official', 2019). 


\section{DISCUSSION}

Regarding the study, we limited ourselves to the statistical data in two case studies. The key element of a successful tourism industry is the ability to recognize and deal with change in terms of a wide range of factors and the way they interact. Not only through promotion but also through introducing infrastructure and modern technology that will enable foreigners to use it at home. Moreover, it is recommended to extend promotion to the overseas guests and to closer countries. Besides, a more active use of modern technology in promotion is of key importance (Raspor \& Mise-Srajlehner, 2017). Full and true comprehension of the rural tourism role is realized through revealing habits of a host, traditional values rooted in the existing culture, and through the establishment of relations amongst the population at the local level (Medojevic et al., 2011).

The ethno village as a part of rural tourism offers great opportunities for new work posts but capacities should be used to a greater extent and the problem of seasonality should also be overcome. All the key aims of the rural development must be defined by the following strategy: the development of a sustainable and efficient agricultural sector, the living standard of the population who lives from agriculture, creation of social and economic conditions in the rural regions, all of it within the National strategy of the rural development.

It is necessary that appropriate incentive measurements be established within the strategic policies of both Slovenia and Bosnia and Hercegovina in order to make more attractive conditions for tourism promotion. It would be also of great importance that these two countries provide better conditions related to their tourist products in order to motivate tourists to stay longer at the destinations and, based on that fact, to ensure that their tourist expenditure could significantly increase. Establishing a creative and innovative tourist product, which would be, at the same time, adjusted according to the specific characteristics and requirements of tourists, would be the right way to achieve that goal (Raspor et al., 2017).

The findings of this survey could be a useful tool in a better understanding of future trends in ethno tourism in terms of the region. It would offer one of the platforms for considering the possibilities for networking of the main tourism subjects in the selected countries of the Balkan region and to use synergy effects in joint promotional and sales activities. Concerning the actual and future importance of the market segment in the total international tourism flow, it is necessary for all the observed countries to perform active measures in marketing research and planning.

\section{ACKNOWLEDGMENTS}

This article was compiled thanks to a bilateral project in the framework of a scientific-technological cooperation between the Government of Bosnia and Hercegovina and the government of Slovenia that took place in 2019 and 2020. 


\section{REFERENCES}

Accommodation establishments capacity, tourist arrivals and overnight stays by tourist accommodation establishments, Slovenia, annually. (2019). Retrieved from https:// pxweb.stat.si/SiStatDb/pxweb/en/20_Ekonomsko/20_Ekonomsko__21_gostinstvo_ turizem_01_nastanitev_02_21645_nastanitev_letno/2164518S.px/

Agencija za statistiku BiH. (2020). Retrieved 20 July 2020, from http://www.bhas.ba/

Aiello, L. (2014). Handbook of Research on Management of Cultural Products: E-Relationship Marketing and Accessibility Perspectives: E-Relationship Marketing and Accessibility Perspectives. IGI Global.

Antunac, I. (1985). Turizam i ekonomska teorija. Zagreb: Institut za istraživanje turizma.

Bijeljina online. (2018). Retrieved 17 June 2019, from https://bijeljina.online/tag/etno-selo-stanisici

Bolnick, S. (2003). Promoting the culture sector through job creation and small enterprise development in SADC countries: the ethno-tourism industry. ILO.

Bunghez, C. L. (2016). The Importance of Tourism to a Destination's Economy.

Burns, P. M., \& Novelli, M. (2008). Tourism and mobilities: local-global connections. CABI.

Carvalho, R., Ferreira, A. M., \& Figueira, L. M. (2016). Cultural and Creative tourism in Portugal. PASOS. Revista de Turismo y Patrimonio Cultural, 14(5), 1075-1082.

Chand, S. (n.d.). 2 Types of Tourism: International and Domestic Tourism. Retrieved from http:// www.yourarticlelibrary.com/tourism/2-types-of-tourism-international-and-domestictourism/14100/

Difference Between Travel And Tourism. (2010). Retrieved 10 March 2017, from https://www. enotes.com/homework-help/explain-difference-between-travel-tourism-180649

Etno selo - official. (2019). Retrieved 16 September 2019, from http://alterural.ba/smjestaj/stanisici/

European Capitals of Culture - Regional Development and Culture. (2019). Retrieved from https:// europa.eu/regions-and-cities/programme/sessions/594_en

European Commission. (2018). Cultural tourism. Retrieved from https://ec.europa.eu/growth/ sectors/tourism/offer/cultural_en

Experience the fairytale of Velika Planina in a valley. (2019). Retrieved from http://sloveniaecoresort. com/en

Goss, J. (2016). What is cultural tourism? Retrieved from https://thegossagency.com/2016/02/03/ what-is-cultural-tourism-2/

Green Tourism - Slovenia - Official Travel Guide. (2017). Retrieved 10 March 2017, from http://m. slovenia.info/en/green-tourism

Heurtier, A. (2017). Ethno-tourism: Are we pushing our curiosity too far? - Sustainablity Story of the Week. Retrieved from https://www.ecocompanion.com/blog/ethno-tourism-pushingcuriosity-far-sustainability-story-week/

Hoang, A. (n.d.). The Differences Between Business vs. Leisure Travelers. Retrieved 10 March 2017, from http://www.e-marketingassociates.com/understanding-differences-business-vsleisure-travelers/

Institute for Economics and Peace. (2016). Global Terrorism Index 2015. Retrieved from http:// economicsandpeace.org/wp-content/uploads/2015/11/Global-Terrorism-Index-2015.pdf

Jaunter, D. (2018). Ethno-Tourism. Retrieved from https://djaunter.com/glossary/ethno-tourism/

Karantzavelou, V. (2017). Ethno tourism market poised for steady growth in the future. Retrieved from https://www.traveldailynews.com/post/ethno-tourism-market-poised-for-steadygrowth-in-the-future 
Korez-Vide, R. (2013). Promoting sustainability of tourism by creative tourism development: how far is Slovenia? Innovative Issues and Approaches in Social Sciences, 6(1), 77-102.

Kos, D. (2018). Lastnik Eko resorta je prepričan, da rušenja ne bo. Retrieved from https://siol.net/ novice/slovenija/lastnik-eko-resorta-je-preprican-da-rusenja-ne-bo-482128

Lacmanović, D. (2006). Prodaja hotelskog proizvoda (1st ed.). Bar, Montenegro: Univerzitet Mediteran Fakultet za turizam, hotelijerstvo i trgovinu-Bar.

Marković, S. i Z. (1972). Ekonomika turizma. Zagreb: Školska knjiga.

Medojevic, J., Milosavljevic, S., \& Punisic, M. (2011). Paradigms of rural tourism in Serbia in the function of village revitalisation. Human Geographies, 5(2), 93.

Mousavi, S. S., Doratli, N., Mousavi, S. N., \& Moradiahari, F. (2016). Defining cultural tourism. In International Conference on Civil, Architecture and Sustainable Development (pp. 70-75).

Ohridska-Olson, R. V., \& Ivanov, S. H. (2010). Creative tourism business model and its application in Bulgaria. In Proceedings of the Black Sea Tourism Forum'Cultural Tourism-The Future of Bulgaria.

Podeželje. (2019). Retrieved from https://www.sloveniaholidays.com/namestitve/turisticnekmetije

Raspor, A., \& Mise-Srajlehner, M. (2017). Globalization challenges in Slovenian tourism sector: from drive in to fly in destination. Retrieved from http://www.eman-conference.org/ uploads/6/5/4/7/65475757/zbornik_radova_eman_2017_final.pdf

Raspor, A., Stranjančević, A., Bulatović, I., \& Lacmanović, D. (2017). Tourism invisible part of exports: the analysis of Slovenia and Montenegro on the Chinese outbound tourism. In A. Maček (Ed.), International Trade-On the Brink of Change (pp. 95-121). Rijeka: InTech.

Richards, G. (2002). From cultural tourism to creative tourism: European perspectives. Tourism, $50(3), 225-233$.

Richards, G. (2003). What is cultural tourism? Weesp: National Contact Monumenten.

Richards, G., \& Wilson, J. (2007). Tourism development trajectories: From culture to creativity? In Tourism, creativity and development (pp. 23-56). Routledge.

Steinberg, A. (2015). How will travel tourism change in the future? Retrieved 5 March 2017, from https://www.quora.com/How-will-travel-tourism-change-in-the-future

Trip.com. (2019). Retrieved 16 June 2019, from https://www.trip.com/hotels/bijeljina-hoteldetail-9879230/etno-selo-stanisici-and-hotel-pirg/?allianceid $=742331 \&$ sid $=1621949 \& u$ tm_source=google\&utm_medium $=c p c \& u t m$ campaign=GG_DSA_All_en_Hotel_NA_ NA_TopList_PC\&ds_cid=71700000049866902\&ds_kid=397000424948721

Verbole, A. (n.d.). Actors, Discourses and Interfaces of Rural Tourism Development at the Local Community Level in Slovenia: Social and Political Dimensions of the Rural Tourism Development Process. Retrieved from http://www.theslovenian.com/articles/verbole.htm

Verbole, A. (1995). Tourism development in the European countryside: Costs and benefits.

Verner, D. (2009). Tourism and Indigenous Peoples-Lessons from recent experiences in eco and ethno tourism in Latin America and the Caribbean. 